\title{
Language, Cultural Identities, and Multiculturalism in Chang-Rae \\ Lee's Native Speaker: A Sociological Perspective
}

\section{Aminur Rashid}

\begin{abstract}
Deep into the novel, an inarticulate sense of unease in the psyche of Henry Park is explored being extremely disturbed, and an outcast. Trapped being in American-Korean identity, he has got his impression on his wife, Lilia beings 'emotional alien', 'yellow peril: neo-American,' 'stranger/follower/traitor/spy'. In addition, she speaks of him being a 'False speaker of Language' because Henry looks listening to her attentively; following her executing language word by word like someone resembling a non-native speaker. In fact, the cultural differences between the Korean-American and the Native American bring tension around the ways the English language is used.
\end{abstract}

\section{Keywords}

Native Speaker, Chang-Rae Lee, Language, Diverse Cultures, Americanization, Crisis of Identity, Psychoanalysis 


\title{
Language, Cultural Identities, and Multiculturalism in Chang-Rae Lee's Native Speaker: A Sociological Perspective
}

\begin{abstract}
Aminur Rashid
If language is as old as consciousness itself, and if language is a practical consciousness-for-others, and, consequently, consciousness-for-myself, then not only one particular thought but all consciousness is connected with the development of the word. The word is a thing in our consciousness . . . that is absolutely impossible for one person, but that becomes a reality for two. The word is a direct expression of the historical nature of human consciousness.
\end{abstract}

\section{Lev Semenovich Vygotsky, Thought and Language}

This essay will analyze the role of language and culture in the construction of identity as represented in Chang-Rae Lee's Native Speaker through a psychoanalytic perspective. Culture is a vehicle for language in a specific society. Therefore, culture and language have a crucial interaction, which leads to distinguishing the speakers of the specific language as native speakers. As Millard (2000) argues, "Issues of language can be both unifying and divisive at a political level and an individual level". Language is a unifying and at the same time, a divisive device, which can unify people with diverse cultures as a nation; and divides people into different groups of ethnics within the same national community. To have a society in which various nations can live equally, cultural diversities should be recognized and acknowledged as a collective agreement by those nations living inside the common society.

Kwang (the Korean politician) in his speech in front of the church mentions to 'strangeness' of the newcomers as a feature or reason for misunderstanding: "whom you believe to be other, the enemy, the cause of the problem in your life. Those who are a different dark color. Who may seem stranger. Who cannot speak your language just yet. Who cannot seem to understand the first thing about who you are" (141). Kwang is a peacemaker and tries to encourage people to recognize the common human characteristics, but such recognition is difficult to achieve in reality. In theory, it is somewhat easy to talk about, as the audience sees two kids shot at Kwang and Henry 
from the top of the church roof at the end of the speech. Therefore, such disagreement between the white and Oriental generations never ends effortlessly.

\section{Critical Discussion}

It is more than one hundred years since the first Korean immigrants arrived in America. Immigrant Koreans arrived in the country in three distinct groups over the last century. The first wave of Korean immigration was the landing of the S.S. Gaelic into Honolulu Harbor in January 13, 1903. Shinae Chun, Director of Women's Bureau, U.S. Dept. of Labor, says that 120 men, women, and children, who made up the first significant group of Korean-Americans, were carried to the harbor by a boat. This group became low-wage laborers on Hawaii's growing sugar plantations. The second wave of Korean immigration began during the Korean War (1950-1953) when the brides of U.S. servicemen arrived in the United States, thanks to the War Brides Act of 1946. In 1952, the McCarran-Walter Act allowed Asians to immigrate in small numbers and eventually to become U.S. citizens. The largest wave of immigration from Korea - and the largest wave of immigration from all of Asia - began with the passing of the Immigration Act of 1965. For the first time in U.S. history, immigrants from around the world, including Asia, were allowed to enter the United States in substantial numbers (Chun 2003).

Koreans are hardworking people. They open their own small businesses. Koreanowned greengrocers, restaurants, and dry cleaners can be seen throughout the country (Chun 2003). Koreans' success lies in some cultural characteristics which appreciate hard working. Those characteristics include speaking quietly and little. Korean culture promotes extreme instructions of "being quiet", "keeping secrets", "exquisite control over face muscles", "working before sunrise to the death of night", regarding "family as a Korean's life, though rarely sees them", and more features from which Koreans are considered by the narrator of the novel as "difficult people".

Chang-Rae Lee's Native Speaker is a profound investigation within the complicated layers of one's personality. The narrator is aware of his "hundredfold" (192) Korean identity. He generously takes the reader's hand and makes a tour through his own hidden dark angles of his mind, showing the reader his "secret rooms", his "identity". This "self-reflexive" feature of the novel helps the reader to discover as much mystery in his/her own life as the capacity allows him/her. The narrator wants "to come out, step into the light, bare himself" (190). Henry (the main character of the novel) has "been raised to speak quietly and little." He is an actor. Since his childhood, he has been taught to play roles by his father, for his father is an actor, too. "Were I an actor, I would have all the material I required"(130).

Henry's language is his main source of problems. He envies how other kids black, young Jewish and his Italian friends talk confidently. He cannot express himself well as a kid, therefore, he mostly listens. When he is six years old, he is sent to Speech Therapy room among other English non-native speakers to learn pronounce English sounds. But he permanently feels this lack of domination on English language. This lack of English domination brings a lack of confidence for him as a kid, a teenager, and then 
as a husband. Henry knows the values that language institutionalizes in people, and is aware of his language shortcomings; therefore, he feels a crisis which originates from his hybrid identity regarding his Korean legacy, and his immigrant parents. The issue of language will be discussed further in the present essay.

Henry's parents are good examples of a Korean's traditional family. His mother is the most difficult person, "My mother was the worst. She was an impossible woman. Of course she was a good mother. I think now she treated it like a job. She wasn't what you'd call friendly. Never warm", "She believed that displays of emotion signaled a certain failure between people" (28).

However, Henry loves his mother. When his father disputes with his wife, he speaks in English, as if he uses English language as a power, as a weapon against his wife "He used to break into it when he argued with my mother, and it drove her crazy when he did and she would just plead, 'No, no!' as though he had suddenly introduced a switchblade into a clean fistfight." Therefore, Henry breaks into their argument and starts "yelling at him, making sure I was speaking in complete sentences about his cowardice and unfairness, shooting back at him his own medicine... using the biggest words I knew, whether they made sense or not" (58).

Both Henry and his father exploit English language as a weapon against each other. The one who masters the language wins. Therefore, language is a power for those who master it. There is a kind of language hierarchy in this novel. Starting from the bottom, Henry's mother does not know English at all; as a result, she is defeated by her husband in their arguments. The father knows English a little; therefore, he cannot find a job he deserves in the Western society. Henry is not a native speaker in America though he is born in New York City. He struggles with communication problems with Lelia, his American wife, and finally, Lelia is a language expert.

Jacques Lacan argues "As the speechless infant develops into a speaking being a subject, he experiences feelings of both loss and power" (Lacan 1977). Loss because, Lacan argues, the infant begins to speak in reaction against unfulfilled desires, the relinquish speechlessness to voice his needs because those needs are not being (immediately) met. In beginning to speak, he experiences power because in asserting himself in speech he discovers that words can sometimes have a transitive effect on the world. "What is attractive to the literary critic about the Lacanian account of subjectivity is its emphasis on language twinned with its openness to the sense that an entire social system might just be at work in the process of learning to speak" (Robbins 2005). Robbins refers to 'Feral Children' who experienced no human contact and normal socialization during their childhood:

The documented cases demonstrate a continuity of features: when the children are rescued, they are rarely able to learn to speak, seemingly rendered incapable of hearing the significance of human speech because of the developmental failures consequent on being deprived of human contact. They can possess neither the logos nor even a minimal capacity for the exchange of signs (Robbins 2005). 
He argues that children who have been deprived of human contact are not able to speak, and consequently they cannot communicate in human ways. Being disabled to use human language, they cannot even think, because thoughts come through language.

Henry cannot express himself well, he remains silent, consequently he is accused by Lelia as "student of life, illegal alien, emotional alien" (5). Henry is forever uncertain of his place in the Western society. As a Korean-American, he is scared that he has betrayed both cultures, and belongs to neither. Robbins discusses further that the kinds of identities "we have developed and lived within are intimately connected to the societies we live in: we draw our models of selfhood from the models that our culture makes available to us" (Robbins 2005). Korean language, as any other languages, is produced through Korean cultural instructions. For instance, 'there are no exact words' for privacy and private space in Chinese (Chang 1993). Lack of a word depicts that there are no concept for this exact word in that particular language, and therefore, there is no such cultural value for that. Likewise, there is no concept for 'individualism' in Korean culture. Because of this lack of individualism concept, Korean identity is collective. There is, for example, no space for first names in Korean culture. Wives and husbands do not call each other's name; instead, they call each other as 'spouse'. "But then he never even called my mother by her name, nor did she ever in my presence speak his. She was always and only 'spouse' or 'wife' or 'mother'; he was 'husband' or 'father' or 'Henry's father"" (63).

A Korean woman comes to work for Henry's father after the death of his mother. She works for them for 20 years. Once Lelia asks Henry about the woman's name, but Henry does not know her name. Lelia is shocked: "This woman has given twenty years of her life to you and your father and it still seems like she could be anyone to you. It does not seem to matter who she is" (60). Henry and his father call the woman simply 'Ah-juh-ma', which means literally 'aunt'. She possesses a common name not a particular name. It reveals that they do not assume her as an autonomous individual who deserves a personal name. It does not relate to the woman but to the Korean culture, which does not bear individualism.

In traditional Korean culture, 'self' is a series of masks and public gestures. Cultural values are given to characteristics such as hard working, being quiet, silence, role playing, and keeping secrets, which lead to regard Koreans as strangers and 'difficult people', at least in the beginning, by Westerns. Korean workers are seen as hard-workers, who work grueling 18-hour days, 7 days a week, and who are going to occupy all the job opportunities in the American society. Korean success in business creates conflict for them with other minority groups. "The most highly visible example of racial tension began on April 29, 1992 in South Central Los Angeles, California, when African American customers revolted violently against Korean American merchants. The result of a long series of racially-charged events, the three days of violent chaos would prove to be the most destructive riot in U.S. history" (Chun 2003).

Henry's father is well and constantly described as a Korean immigrant model 
throughout the novel. "For him, the world (this land, his chosen nation) operated on a determined set of procedures, certain rules of engagements. These were the inalienable rights of the immigrants"(43-4). He admires Americans or any other person for their appearance but not openly. He makes fun of, for example, Joe Namath, a TV showman, but he uses the same things Joe does, "the little green bottle of musky potion that Joe also used", "He would have probably admired John Kwang- at least for his appearance. Though not openly, of course" (127). He possesses no good knowledge of English language. Therefore, he cannot communicate well with Americans, especially blacks. He is not fluent in English; therefore, he is not able to work in the professions in which he was trained in Korea. He has a master degree in engineering, but he works in a vegetable store. He is a man of family, but pays no good attention to his wife's and his son's emotional feelings. He has not learnt to love as Henry says "For most of my youth I was not sure that he had the capacity to love. He showed great respect to my mother to the day she died - I was ten - and practiced for her the deepest sense of duty and honor, but I never witnessed from him a devotion I could call love. He never kissed her hand or bent down before her"'(53).

Henry is an actor. He plays different roles well, hides his emotions, keeps his secrets, and says a lot of lies to Lelia (his wife) (6). In a phrase, he is a "spy". Therefore he can occupy a spy position: "I had always thought that I could be anyone, perhaps several anyones at once. Dennis Hoagland and his private firm had conveniently appeared at the right time, offering the perfect vocation for the person I was, someone who could reside in his one place and take half-steps out whenever he wished." He is satisfied with the kind of job which requires some qualities Henry already possesses, such as role playing. "I thought I had finally found my truest place in the culture"(118).

$\mathrm{He}$ is an industrial spy for a strange firm with unknown clients. "Our clients were multinational corporations, bureaus of foreign governments, individuals of resource and connection"(16). The individual he is spying on is called 'subject'; they could be "foreign workers, immigrants, first-generationals, neo-Americans", "We generated background studies, psychological assessments, daily chronologies, myriad facts and extrapolations. These in extensive reports."(16).

Dennis Hoagland, the boss, makes the plans, and appoints the spies for appropriate missions or "assignments", as Henry calls them. John Kwang is his new subject. "I can write three or four pages on my subject and then another page of breezy analysis in less than an hour. I am supposed to do it this way, precisely but fast" (189). At the beginning, Kwang is only a 'subject', and does not possess any meaningful identity for him. Henry is a dutiful spy "I am to be a clean writer, of the most reasonable eye, and present the subject in question like some sentient machine of transcription." He does not permit his moral interfere with his job. Judgment is not his task "I leave to the unseen experts the arcane of human interpretation" (189).

Although Henry knows his job, "his appointed plan" well, he approaches Kwang's inner self "who he was to himself, the man he beholds in his most private mirror.", which is not a wisely deed a professional spy does. Henry is impressed by 
Kwan's personality, unlike what he thought at first when Hoagland mentioned Kwan's name. "I thought I could peg him easily; were I an actor, I would have all the material I required" (130).

Henry makes a lot of flash backs between his father and John Kwang. Kwang is a Korean politician, though there are some significant differences between them, he displays some cultural similarities as a Korean immigrant. Henry sees some of their appearance characteristics look like each other (Kwang's and his father's), as if the narrator were going to state that Koreans in any position of literacy, political situation, and age had a lot in common. For example, Kwang is a man of family, like Henry's father. "His neatly clipped black hair ... reminded me of my father's head" (125), their way of dressing, (127), and their "short Korean legs" (128).

However, working with Kwang, Henry finds somehow a new family. When he reports to Hoagland, he feels he is reporting something private about his own parents "as if I were offering a private fact about my father or mother to a completely stranger in one of our stores"(137). Henry feels a kind of love, family love or family bound with Kwang, and says "perhaps this was because John Kwang constantly spoke of us as his own, of himself as a part of us. Though he rarely called you a brother, sister, son" (137).

Kwang introduces Korean culture to Henry from a new angle, and makes him acquainted with his legacy. He remarks "we misapply what our parents taught us"(180), or reminds Henry "Don't be so hard on your father... likely I know, you are right. But I understand his feeling more than I ever have" (183). Through his sessions with Luzan (Henry's previous subject) and his working for Kwang, Henry asks himself "Who have you been all your life?"(191). And some uncertainties grow in his conscious: "in some moments then, I don't know how long, exactly, I forgot the entirety of what I was doing. I lost- or better, misplaced- the very reason why I was there...there was nothing to report, certainly, nothing worth commentary" (184), which can be well defined in terms of identity crisis. Henry does not try to report on Kwang the way he is supposed to by Hoagland. "But there is one more version I want to write for Hoagland, for the client, for the entire business of our research. The greater lore I can now see" (196). The ethical conflicts of Henry's job are never really resolved. "For how do you trail someone who keeps you so close? How do you write of one who tells you more stories than you need to know? Where do you begin, and where are you able to end?" This new version is "the leap of his identity no one in our work would find valuable but me" (196). Henry finds out that throughout his working on this 'assignment', he was in fact searching his own identity "I am here for the hope of his identity, which may also be mine". He is looking for his true self "to catch a glimpse of who I truly was" (300).

Lelia is a white, a native speaker, "the standard-bearer" (11) in terms of English language. She comes from an entirely different background. She does not have a language problem. She is a native speaker, a language teacher. She stands on the opposite end of the line which leads to Henry's language shortcomings. She is equipped with what Henry lacks, which is language-power.

Before anything, Henry notices how closely he is listening to her: "She could 
really speak...she was simply executing the language. She went word by word" (9). Henry knows the values and power that language institutionalizes in people, and is aware of his language shortcomings. Therefore, he chooses Lelia, and her language abilities, to construct his own identity as an American. Their marriage can be a symbol for unifying of East and West, the very goal of politicians like Kwang in an American society. However, such kind of unification is not an easy effort. It takes ten years for Lelia to know some of Henry's characteristics, and write them down on a piece of paper: "Surreptitious, B+ student of life, illegal alien, emotional alien, Yellow peril: neoAmerican, stranger, follower, traitor, spy [...]" (5) or so says his wife, in the list she writes upon leaving him.

Henry is, in top of her list, a "surreptitious" for her. Indeed, his Korean cultural instructions taught him to remain as quiet, silent, and mysterious as possible. In such manners, Koreans are as hurt as Westerns. "We perhaps depend too much often on the faulty honor of silence; use it too liberally and for gaining advantage" (89). To clarify this kind of cultural 'silence' which Koreans depend on, and to demonstrate Korean and Western cultural diversities, it may be useful to refer to the part in which Janice Pawlowsky, the Scheduling Manager in Kwang's office, shares her love experience with Henry. She tells him she loved John Kim, a Korean college student, and how they broke up. She wants to go back to her parents' home in Chicago, and asks John to go with her, but he does not want to go with her.

They have a huge fight: “Actually, I mostly yelled at him. He wouldn't say anything back. I called him later from Chicago but he wasn't home and his mother answered. She had no idea who I was. She never knew I existed. He never told them." John's mother tells Janice "very politely that I shouldn't call back" (88). Janice does not understand him. He never calls her. She asks to Henry "Is it a Korean thing? I mean, what kind of person does that? Everything was great between us. We had great sex, too, and that doesn't happen a lot in college. But now I have to think none of it was very good. It was like he'd done his time with me, with a white girl, and then it was over. I almost still hate him." (88). Henry thinks within himself "I knew I could have tried to comfort her, perhaps telling her how John Kim was probably just as hurt as she was and that his silence was more complicated than she presently understood"(88). However, he keeps silent again.

Henry compares Janice's and John Kim's love story failure with his own. "I showed Lelia how this was done, sometimes brutally, my face a peerless mask, the bluntest instrument" (89). This Korean silence and failure to talk freely seems an old misunderstanding in terms of language and culture. Talking with Lelia, Henry feels "I tried to answer but I couldn't. I wanted to explain myself, smartly, irrefutably. But once again I had nothing to offer" (118). He, like most immigrants, lacks the English language power. Henry and John suffer the same cultural problem in terms of 'silence'. Henry envies how other kids, black, Jewish and his Italian friends talk confidently with their parents. "When I was a teenager, I so wanted to be familiar and friendly with my parents like my white friends were with theirs. You know, they'd use curses with each other, 
make fun of each other at dinner, maybe even get drunk together on holidays." (205)

But the Korean teenagers cannot share their love experiences with their parents. Mostly, the Korean parents are not aware of their children's relationships with their friends of opposite sex, because it is not traditionally and culturally appreciated. Familial affection is marked by its total absence. Ideas such as 'falling in love' are considered 'shameful', a family disgrace. Marriage is seen above all as a duty, an arrangement between two families. Henry is increasingly aware of the formality of his relationship with his father in particular. This is both a cultural issue: fathers and children are not supposed to show each other physical affection in Korean culture, and also a personal one. Once Henry tells Lelia, "I wanted just once for my mother and father to relax a little bit with me. Not treat me so much like a son, like a figure in a long line of figures. They treated each other like that, too. Like it was their duty and not their love" (205).

The kind of person one becomes is a very direct result of the childhood one lives through (Robbins 2005). Although Henry is brought up in America, he is living within a Korean home, with Korean language and culture. Hybridism is central to the story which blends traditional and new elements. He is not American enough to tolerate his individualism, nor Korean enough to knock that individualism out of him. He is affected by identity crisis. His crisis is because of living on the border between cultures, and exploring possible meanings of identity in two very different cultural models, Korean and Western.

There are a lot of differences between Lelia and Henry, which they ignore at first, but their son's death helps Lelia to look carefully into Henry and find the differences, which seem to her at first his shortcomings. Then, it seems to her that their only common reason to live with each other (their son) has been removed, so she leaves himand goes to islands for a while.

Henry does not talk about his son's death directly. It depicts that it is difficult for him to talk about his profound feelings. He approaches the issue cautiously after providing some long backgrounds. "Our boy, Mitt, was exactly seven years old when he died." He suffers in his silence. He does not talk about his suffering and pain with his wife, therefore, Lelia assumes that Henry is neutral about their son's death. They do not talk about Mitt until Lelia comes back from islands. Lelia tells Henry "Just think about it. You haven't said his name more than four or five times since it happened. You haven't said his name tonight. Maybe you've talked all this time with jack about him, maybe you say his name in your sleep, but we've never really talked about it, we haven't really come right out together and said it, really named what happened for what it was." Again, their relationship suffers from Henry's Korean silence, his avoidance to show his feelings.

Among the other features in Lelia's list, there is a dangerous word: "Stranger". The very existence of this word reveals that Lelia (West) does not know Henry (East) well enough to have a healthy coexistence with him. Kwang in his speech in front of the church mentions to this strangeness as a feature or reason for misunderstanding: "whom you believe to be other, the enemy, the cause of the problem in your life. Those who are 
a different dark color. Who may seem stranger. Who cannot speak your language just yet. Who cannot seem to understand the first thing about who you are"(141). He is a peacemaker, but such recognition is difficult to achieve in reality. In theory, it is somewhat easy to talk about, as the audience sees two kids shot them at the end of Kwang's speech.

Therefore, such disagreement between the white and oriental generations never ends effortlessly, because important economical and political elements are involved. Social pressures should be considered in analyzing the situation, as well. In April 29, 1992, African American customers revolted violently against Korean American merchants. This tragedy shook the Korean American population to the core. Of the $\$ 850$ million in estimated property damage, Korean Americans sustained 47\% or $\$ 400$ million of that damage, and of the 3,100 businesses destroyed, approximately 2,500 of them were owned by Korean Americans (Chun 2003). In fact, the conflict was a result of a far more complex situation involving two minority groups who were both plagued by a history of racial inequality and oppression.

In spite of the tragic events, the Korean American community also made hopeful progress as a direct result of the riots. For the first time in American history, Korean Americans found a unifying voice. They organized to stop the rioting, to ultimately find peace with their African American neighbors, and to move ahead in cooperation with one another (Chun 2003).

\section{Conclusion}

Identity is not something fixed since birth day. Julia Kristeva's term can be applied here for identity though she uses it for subjectivity. She employs the term 'subject in process', and argues that "subjectivity is never complete, but is always in the process of being made and remade by the competing forces of the symbolic order and the semiotic, a space made up of the demands of the body and of the non-signifying parts of language, such as speech rhythms, sounds, intonations and other non-semantic gestures" (Kristeva 1984). Identity is made and remade in an instant process. To find out who it is, it is required to work out who has been, and how s/he has got to be her/him. Culture and language are among the most significant factors of the mentioned process of making identity. Those people who live in foreign countries, as migrants, refugees and exiles are exposed to two languages and cultures, which are sometimes completely different, in this respect, Koreans are living in a culture dominated by a white hegemony.

Language, as the title of the novel shows, is the central issue for the narrator around which other significant subjects move. Nothing can find its true meaning unless the main problem is decoded. When Henry finds his own native language, he finds his place on both Korean and Western worlds. Kwang and Lelia help him in their own ways. Kwang makes him familiar with Korean culture, language, old songs, lyrics, and music. Shows him how Henry can live in a Western society, be an American citizen, and still be a Korean. "They are every shape and color but they still share this talk, and this is the other tongue they have learned, this must be the special language" (316). Kwang, as a 
Korean-American, is somewhat Henry's history. Henry studies Kwang no more for his 'appointed plan' but to find his own 'identity' (314). Lelia shows him, through tutoring young non-English students, how every language is a native language "Now, she calls out each one as best as she can, taking care of every last pitch and accent, and I hear her speaking a dozen lovely and native languages, calling all the difficult names of who we are" (324). Noam Chomsky, the famous linguist, states that "everyone is a Native Speaker of the particular language that the person has grown in [their]... brain." (Robbins 2005).

English can be an immense obstacle for those who are living in an English speaking society, yet do not master it. Language is a unifying and a divisive feature. Cultural diversities should be recognized and acknowledged as a collective agreement by various nations living inside one society. Finally, Henry becomes a native speaker of himself by learning to express his real self in his own language, regardless of being a Native Speaker or a Non-native Speaker.

Politicians, like Kwang, are peacemakers and try to encourage people to recognize the common human characteristics, but such recognition is difficult to achieve in reality. In theory, it is somewhat easy to talk about, as the audience sees two kids shot them from the top of the church roof at the end of the speech. Therefore, such disagreement between the white and Oriental generations never ends effortlessly.

\section{Works Cited}

Chang, Jung. Wild Swans: Three Daughters of China. London: HarperCollins, 1993.

Chun, Shinae. Talking Points: Korean American Coalition National Convention.

Centennial of Korean Immigration to the United States, January 11, 2003

http://apa.si.edu/Curriculum\%20Guide-Final/unit1.htm

Kristeva, Julia. Revolution in Poetic Language [1974]. Trans. Margaret Waller. New York: Columbia University Press, 1984.

Lacan, Jacques. The Four Fundamental Concepts of Psycho-analysis. Tranns. Alan Sheridan. London: Hogarth Press, 1977.

Marshall, Brenda, K. Teaching the Postmodern: Fiction and Theory. New York, London: Routledge, 1992.

Millard, Kenneth. Contemporary American Fiction: An Introduction To American Fiction Since 1970. Usa: Oxford University Press, 2000

Murfin, Ross; and Supryia, M. Ray. "The Bedford Glossary of Critical and Literary

Terms.”Boston, New York: Bedford/St. Martin's, 2003.

Robbins, Ruth. Transitions: Subjectivity. China: Palgrave Macmillan, 2005.

Zahavi, Dan. Subjectivity and Selfhood: Investigating the First-Person Perspective. Massachusetts, London, England: MIT Press Cambridge, 2006. 
Aminur Rashid, Language, Cultural Identities, and Multiculturalism in Chang-Rae Lee's Native Speaker

\section{The Author}

\section{Aminur Rashid}

Email: akmaminur.rashid@gmail.com

\section{The Article}

Date sent: 10/12/2020

Date revised: 19/01/2021

Date Accepted: 21/01/2021 